Annales Missiologici Posnanienses t. 23 (2018), s. 23-39

doi: 10.14746/amp.2018.23.2

\author{
GRZEGORZ ADAMIAK \\ Uniwersytet Kardynała Stefana Wyszyńskiego w Warszawie \\ Wydział Teologiczny
}

\title{
Początki ewangelizacji Islandii
}

Choć położona na krańcach europejskiego horyzontu, Islandia potrafi skupić na sobie spojrzenia zaintrygowanych nią ludzi. Jej popularność bazuje głównie na atrakcyjności turystycznej, a także, oczywiście, przy zachowaniu właściwych proporcji, na usytuowaniu na szlaku współczesnych migracji. Dzięki temu drugiemu czynnikowi odnotowuje się również odrodzenie chrześcijaństwa w tym kraju. Z jednej strony bardzo wyraźnie widać tutaj, dostrzegane i gdzie indziej, odcinanie się bogatego społeczeństwa od chrześcijańskich korzeni, z drugiej zaś widoczne jest w ostatnich latach budujące ożywienie i kilkakrotny wzrost liczby wiernych Kościoła. Warto zauważyć tu pewną analogię do samego odkrycia i zasiedlenia tego skrawka lądu na północnym Atlantyku w dobie średniowiecznych migracji. Interesujące i oryginalne są także okoliczności przyjęcia chrześcijaństwa w początkach historii tego kraju.

\section{Odkrycie Islandii}

Pierwsze wzmianki i niezbyt jasne informacje dotyczące Islandii wiążą się z greckim geografem, astronomem i podróżnikiem Pyteaszem (ur. około 350 r. przed Chr.). Wyspę identyfikuje się $\mathrm{z}$ opisywaną przez niego Ultima Thule. Pyteasz relacjonuje, że w czasie jednej ze swych podróży dotarł do lądu oddalonego o sześć dni rejsu od Wysp Brytyjskich, na którym to lądzie słońce świeci 24 godziny na dobę. Niestety, całe dzieło opisujące tę wyprawę na wschód i północ Europy zaginęło, a relacja z niej jedynie fragmentarycznie zachowała się $w$ innych jego pismach. $Z$ relacji wynika także, że był to teren niezamieszkały. Nie ma również całkowitej pewności, czy widzianą przez 
podróżników krainę należy utożsamiać z północnymi krańcami Norwegii, Szetlandami czy Orkadami. Gdy jednak ostatecznie odkryto Islandię, to tej właśnie wyspie przypisano miano Ultima Thule, tożsame z końcem znanego wówczas świata (Njardvik 12).

Zagadką i pytaniem bez odpowiedzi zdaje się także obecność Rzymian na wyspie. Na początku XX w. odnaleziono w kilku miejscach na Islandii rzymskie monety bite w latach 270-305. Możliwe, że należały one do osadników, którzy zasiedlali wyspę na przełomie IX i X w. Takie monety były jednak w tamtym czasie bardzo rzadkie. Wydaje się możliwe, że pozostawili je tam Rzymianie, którzy mogli przybyć do południowo-wschodnich wybrzeży wyspy w IV w., żeglując ze Szkocji do Norwegii. Kwestia ta pozostaje jednak otwarta i trudno o jednoznaczną i pewną odpowiedź (Njardvik 12-13).

Według legendy pierwszymi odkrywcami i mieszkańcami Islandii byli mnisi irlandzcy, którzy dotarli na wyspę około 800 r. (Wittman 615). Niektóre źródła mówią jednak o jeszcze wcześniejszym odkryciu przez nich wyspy. W latach 500-800, w czasie kryzysu dotykającego rodzącą się jeszcze wówczas chrześcijańską Europę, Irlandia jawiła się jako silny ośrodek chrześcijaństwa na Zachodzie. Była ona miejscem powstania i rozwoju Kościoła monastycznego. Zjawisko to określane jest nawet jako „rewolucja monastyczna” (Miotk 161). To z niej wywodziło się wiele inicjatyw i prądów ożywiających i kształtujących ówczesne chrześcijaństwo. Jednym z nich była peregrinatio pro Christi amore. Z tego nurtu wyrasta m.in. św. Brendan, który rzekomo dotarł na Islandię (Thule) już w VI w. Navigatio Sancti Brendani opowiada o podróży Brendana i jego 17 towarzyszy w poszukiwaniu pustyni na oceanie. Brendan i jego towarzysze byli przygotowani raczej do rejsu po jeziorze, a nie po nieprzyjaznym śmiałkom Atlantyku, jednak po czterdziestu dniach żeglugi dotarli do ziemi obiecanej mnichowi przez anioła. Tylko duch głębokiej wiary i radykalnej ascezy może tłumaczyć ich determinację i wyczyn. Z opisu spotkania z warunkami panującymi na wyspie wynika, że obiecana Thule miała raczej posmak piekła niż pożądanego nieba. Mnisi wystawieni byli na niezwykle trudne warunki klimatyczne Islandii. Brendan zachęcał ich jednak, by uzbrojeni w duchowy oręż - stawili czoła wyzwaniom samego piekła. Fizyczne doświadczenie piekła mogło być o tyle bardziej realistyczne i przejmujące, że mnisi byli prawdopodobnie świadkami erupcji Hekli (Scherman 70-71).

W 825 r., spod pióra innego irlandzkiego mnicha imieniem Dicuil, wyszło dzieło De mensura orbis terrae. Dicuil opisuje w nim wpierw archipelag zasiedlony przez irlandzkich pustelników już od przeszło stu lat. Z opisu wynika, że były to Wyspy Owcze. Nazwa wzięła się od owiec, które podobno mnisi przywieźli ze sobą na odkryte w początkach VIII w. wyspy. W momencie powstania dzieła mnisi musieli jednak opuścić spokojne dotychczas miejsce i szukać innego schronienia przed zagrażającymi im wikingami. Dicuil pisze 
następnie, że około 795 r. spotkał mnichów, którzy mieszkali na wyspie o nazwie Thule. Według ich relacji nigdy latem nie zapadają tam ciemności, tak, że w środku nocy, jak w jasny dzień, można wyrywać wszy z koszuli. Dicuil jest na tyle wiarygodnym autorem, iż można zaufać jego relacji; wynika z niej, że Islandia była już wówczas odkryta i zasiedlona pod koniec VIII w. Dicuil nie podaje jednak, od kiedy dokładnie mnisi irlandzcy przebywali na Thule. Obecność mnichów iroszkockich potwierdzają także nazwy miejscowości, nadane przez późniejszych osadników. Nazwy, takie jak Papey, Papafiordur, Papós czy Papafell, są nawiązaniem do papar - ojców, których być może spotkali pierwsi stali na wyspie osadnicy. Wskazują one również, że mnisi żyli nie tylko na południowych wybrzeżach Islandii, ale także na północnym wschodzie wyspy. Prawdopodobnie mieszkali oni w niewielkich osadach i utrzymywali się głównie z rybołówstwa. Możliwe jest również, że przywieźli ze sobą kozy i owce (Njardvik 13-14).

Pozostałością po iroszkockim osadnictwie i obecności jest także nazwa Kirkjubæjarklaustur, oznaczająca dosłownie kościół z farmą i klasztorem. Aż do dzisiaj miejscowość ta stanowi jakby zieloną oazę na południu Islandii. Przez około 80 lat mnisi byli, bez przeszkód ze strony człowieka, niepodzielnymi i jedynymi panami Islandii. W 874 r., wzdłuż południowego brzegu Islandii, mogło przebywać ich nawet ponad tysiąc (Scherman 72-73).

\section{Zasiedlenie kraju}

Jednak stałe i docelowe zasiedlenie Islandii nie było ostatecznie dziełem mnichów. Kolonizacja wyspy była dziełem Normanów. Odkrycie i zasiedlenie wyspy zasługuje na uwagę i jest pod pewnym względem unikalne. Żaden inny naród w Europie nie ma bowiem swojej historii spisanej od początku, z podaniem imion, genealogii i krótkich biografii pierwszych osadników. $\mathrm{Na}$ podstawie tych źródeł można odtworzyć dane dotyczące około 400 osadników i wielu innych postaci związanych z zasiedleniem Islandii. Głównym źródłem informacji o tym początkowym okresie historii wyspy jest Landnámabók Księga o zasiedleniu (Magnússon 9).

Pierwszym z odkrywców był Naddodd. Nie mamy o nim zbyt wielu informacji, ale to on, jako pierwszy Skandynaw, postawił stopę na Islandii. Około 860 r. wyruszył z Norwegii w kierunku Wysp Owczych. Jego okręt został jednak wyrzucony przez sztorm na wschodnie wybrzeże Islandii, w okolicach Reydafiordur. Przybił on do brzegu na końcu fiordu, a wyszedłszy na ląd, nie spotkał żadnych śladów obecności człowieka. Choć było lato, zaczął padać śnieg, więc odkrywcy opuścili to miejsce, nadając mu nazwę „Śnieżna Ziemia" (Scherman 72). 
Jednak według innej redakcji Księgi o zasiedleniu Naddodd nie był wcale pierwszym skandynawskim odkrywcą Islandii. Być może był nim Gardar Svavarsson. Przybił on rzekomo do wschodnich brzegów Islandii, w okolicach Hornafiord. Nie pozostał tam jednak, ale popłynął wzdłuż brzegu, odkrywając przy okazji, że ląd jest wyspą, i dotarł aż na jej północ. Wybudował dom w dzisiejszym Husaviku, gdzie spędził zimę. Po powrocie do rodzinnej Szwecji był pełen zachwytu dla odkrytego przez siebie lądu, który zaczęto nawet nazywać Wyspą Gardara (Scherman 72). Tezę o pierwszeństwie Gardara potwierdza także wysłanie do Islandii jego syna Uniego. Król Harald Pięknowłosy (855-933) posłał go do Islandii w celu przejęcia władzy, uczyniwszy wcześniej earlem. Misja ta wydaje się łatwiejsza do realizacji, gdy założy się, że Uni mógł powołać się na to, iż jego ojciec odkrył wyspę. Wśród badaczy nie ma jednak zgody w tej kwestii (Njardvik 15).

Następnym kolonizatorem Islandii był Flóki Vilgerdarson. Wyruszył on z rodziną, towarzyszami i trzodą, z zamiarem osiedlenia się na wyspie. Flóki zabrał na pokład swej łodzi trzy kruki, które miały służyć jako pomoc w odnalezieniu lądu i dostaniu się na wyspę, stąd też znany jest w historii jako Hrafna-Flóki (isl. hrafna - kruk). Wyprawa Flóki'ego dotarła do Islandii w okolicach Hornafjord. Żeglarze popłynęli wzdłuż linii brzegowej na południe, opłynęli Półwysep Reykjanes i wpłynęli do zatoki nazwanej na cześć jednego z wojowników Zatoką Faxa (isl. Faxafloi). Ostatecznie Flóki i jego towarzysze osiedli aż w Vatnsfiordur, w Fiordach Zachodnich. Przez całe lato polowali i łowili ryby, ale zaniedbali przygotowanie zapasów siana dla trzody, dlatego ich osiedlenie zakończyło się niepowodzeniem. Trwałym owocem tej wyprawy było stworzenie nazwy dla wyspy, która odtąd określana jest jako Islandia (Njardvik 15; Scherman 73-74).

Niezwykle ważną, wręcz kluczową postacią w historii zasiedlenia Islandii jest Ingólfur Arnarson. Oskarżony, wraz ze swoim przyrodnim bratem, o zabójstwo, musiał opuścić rodzinną Norwegię. Najpierw bracia sami przybyli na Islandię, aby rozeznaniać sytuację, a po dwóch latach, w 874 r., powrócili na wyspę z rodzinami i dobytkiem w celu jej trwałego zasiedlenia. Polecając się prowadzeniu bogów, osiedli w Reykjaviku. Rok 874 (według niektórych: 870) stanowi początek ery trwałego osadnictwa na Islandii i tym samym początek historii tego kraju i narodu. Data ta jest początkiem epoki zasiedlania Islandii, początkiem państwa islandzkiego, ale także nowej ery w historii całej Europy (Njardvik 15-16).

Rok 874 jest zgodnie uważany za początek trwającego do 930 r. okresu osadnictwa w Islandii. Wskazuje się kilka powodów wzmożonego zainteresowania wikingów kolonizacją wyspy. Pierwszym było dążenie do zachowania wolności i niezależności w obliczu rosnącej w siłę władzy królewskiej Haralda Pięknowłosego w Norwegii, w latach 862-930. Wskazuje się ją też jako 
reakcję na ucisk ze strony monarchy czy wręcz jako reakcję na jego tyranię. Była to także zwykła forma ucieczki przed zorganizowanym aparatem państwowym. Podkreśla się też często element ideologii wolności. W zasiedleniu Islandii należy także widzieć kolejny krok ekspansji i migracji widocznych w północnej Europie w epoce wikingów. Sprzyjającym faktorem był również ówczesny postęp techniczny, pozwalający na usprawnienie żeglugi. Motywem tego zjawiska było, normalne dla migracji, poszukiwanie lepszych warunków życiowych. Ekspansja w stronę Islandii stanowiła też następstwo wypierania wikingów z Wysp Brytyjskich (Njardvik 15-16; Scherman 75-78).

Okres zasiedlania trwał około 60 lat (874-930). Pod koniec tego etapu zamieszkana była większość terenów położonych wzdłuż wybrzeży; niezamieszkany pozostał interior. Trudno określić liczbę mieszkańców w roku 930; szacuje się ją nawet na około 20-45 tys. Znaleźli się wśród nich osadnicy i ich rodziny, krewni, przyjaciele, służba, niewolnicy. Wielu spośród osadników było liczącymi się przywódcami klanów w Norwegii czy na Wyspach Brytyjskich (Magnússon 10-11).

\section{Początki państwowości}

Pierwotne społeczeństwo Islandii było więc typowym społeczeństwem składającym się z imigrantów. Pierwsi Islandczycy pochodzili głównie z Norwegii, ale także z Irlandii, Szkocji, Hybrydów. Wywodzili się z kręgu kultury celtyckiej, lecz wśród kolonizatorów byli też ludzie pochodzący z kręgów galijskich - głównie żony, służba i niewolnicy (Byock 9).

Za koniec epoki zasiedlania uznaje się rok 930, który jest jednocześnie rokiem powstania Althingu i początkiem mającej przetrwać 330 lat islandzkiej, niezależnej wspólnoty narodowej. Althing uznawany jest za pierwszy w świecie parlament. Powstanie Althingu powszechnie uważane jest za jedno z najbardziej znaczących wydarzeń w całej historii Islandii, choć wiedza o jego początkach jest dość skąpa. Zbierał się on corocznie na Równinie Zgromadzenia, około $50 \mathrm{~km}$ od Reykjaviku. Nie był to jednak parlament w naszym współczesnym rozumieniu. Althing dzielił się na część odpowiedzialną za uchwalanie prawa i część sądowniczą. Obydwie części składały się z przywódców lokalnych rodów. Całe państwo podzielone było na 13 okręgów, ze swoimi naczelnikami i lokalnymi zgromadzeniami (thing). Obrady Althingu trwały zawsze dwa tygodnie, a rozpoczynały się w czwartek między 18 a 24 czerwca. Każdy naczelnik musiał uczestniczyć w jego obradach, najpóźniej o wschodzie słońca w dniu rozpoczęcia zgromadzenia. Althing był miejscem podejmowania decyzji politycznych i rozstrzygania spraw sądowych, ale także miejscem prowadzenia interesów, dobijania targów. Obrady Althingu stanowiły też 
okazję do spotkań rodzin i przyjaciół mieszkających w różnych częściach kraju. Równina Parlamentu była w ciągu dwóch letnich tygodni nie tylko stolicą polityczną, ale także kulturalną oraz tętniącym życiem centrum społecznym (Njardvik 25-29; Scherman 104-110).

Powstanie Althingu utrwaliło specyficzny rodzaj ustroju państwowego Islandii. Zamiast typowej wówczas w Europie władzy monarszej z silną pozycją króla, kontrolę nad autonomicznymi dzielnicami sprawowali lokalni wodzowie (Stórgódai). Ostatecznie jednak system ten załamał się po upływie około 300 lat. Jedną z głównych przyczyn stanowiło skoncentrowanie wymiaru sprawiedliwości $\mathrm{w}$ rękach kilku najzamożniejszych rodzin. Te z kolei przekupywały większość lokalnych nadzorców, co zaowocowało formami wyzysku wolnych obywateli. W konsekwencji doprowadziło to do wewnętrznych napięć, a następnie do wzmożonej aktywności norweskiego króla Hakona IV. Wykorzystał osłabienie społeczeństwa, porozumiał się z częścią islandzkich naczelników i połączył unią Islandię z Norwegią. Okres istnienia niezależnego państwa islandzkiego kończy się definitywnie w latach 1262-1264 (Byock 348-352).

Doniosłym wydarzeniem $\mathrm{w}$ procesie tworzenia się narodu $\mathrm{i}$ państwa islandzkiego było przyjęcie chrześcijaństwa. Silnie wpisuje się ono na listę najważniejszych wydarzeń stanowiących początek historii tego kraju. Pierwszy i najdłuższy zarazem okres istnienia wolnego i samodzielnego państwa pokazuje także niepodważalne znaczenie aktu dokonanego w roku 1000 przez Althing.

\section{Wspólistnienie chrześcijaństwa i religii pogańskiej}

Kraje skandynawskie były, ze względu na położenie geograficzne, odizolowane od reszty Europy oraz wykształciły właściwą sobie tradycję i kulturę. Koncentrowała się ona w dużej mierze wokół sztuki wojennej, której wszystko inne podporządkowano. Nie oznacza to jednak wcale, że mieszkańcy Północy byli wyłącznie barbarzyńcami. Mieli swoją wysoko rozwiniętą kulturę oraz własne wierzenia (Neill 105-106). Ludy skandynawskie, w tym także kolonizatorzy Islandii, stanowili więc specyficzną grupę, ku której skierowany był wysiłek misyjny Kościoła.

Zapewne pierwszy okres obecności chrześcijaństwa na wyspie to czas kilkudziesięcioletniego pobytu mnichów irlandzkich. Monastycyzm iroszkocki odegrał wielką rolę w chrystianizacji Europy. Jej areną były chociażby Wyspy Brytyjskie i zachód Europy. Śmiało można też mówić o morskiej, a nawet oceanicznej, misyjnej ekspansji mnichów iroszkockich. W owej peregrinatio nie chodziło o zwykłe, geograficzne przekraczanie granic w celu poszukiwania spokojnego miejsca za morzem. Motywem była wewnętrzna przemiana, która 
mobilizowała do nieustannego opuszczania ojczyzny ziemskiej dla pozyskania ojczyzny niebieskiej. Fenomen nieustannego pielgrzymowania trwał przez siedem stuleci, począwszy od VI w. Miał on także, o czym warto pamiętać, charakter misyjny (Miotk 163-164). W konsekwencji, w większości przypadków monastycyzm irlandzki nie miał tylko i wyłącznie akcentu anachoreckiego. Zapewne i na Islandii nie przybrał takiego wymiaru, ale nie mogło tutaj odbywać się, z racji niezasiedlenia wyspy, typowo misyjne oddziaływanie. Nie stali się też mnisi iroszkoccy tymi, którzy przyczynili się do schrystianizowania zasiedlających wyspę wikingów. Historia milczy na temat ewentualnego spotkania jednych i drugich, nie dostarcza informacji, w jaki sposób i dlaczego pierwsi mieszkańcy wyspy ustąpili przed nowymi jej panami. Intryguje fakt, że skandynawscy osadnicy nie zasiedlili choćby założonej przez mnichów osady Kirkjubæjarklaustur. Być może powodem było to, że nie zasiedlali oni miejsc, w których dokonano morderstwa (Scherman 80).

Pierwsi osadnicy na Islandii byli przeważnie poganami z całym panteonem bóstw nordyckich (Aðalsteinsson 46; Scherman 113-117). Chrześcijaństwo było jednak między nimi obecne. Przybyło przede wszystkim wraz z osadnikami pochodzącymi z Wysp Brytyjskich. Wspomina się sześciu ochrzczonych osadników, stamtąd pochodzących (Aðalsteinsson, 27). Einar Pálsson wymienia na podstawie Księgi o zasiedleniu następujące osoby i miejsca ich osiedlenia: Hildir, Hallgeir i Ljót (Landeyjar), Audr (Dalir), Thórunn (Eyjafiordur), Helgi (Kjalarnes) i Orlygur Hrappsson (Esjuberg) (Pálsson 22).

Należy jednak pamiętać, że większość kolonistów stanowili przybysze z Norwegii. Na wymienianych 400, około 130 pochodziło z Norwegii, a około 50 z Wysp Brytyjskich (Aðalsteinsson 30). Chrześcijanie obecni byli także wśród celtyckiej służby i niewolników. Większość spośród nich to wyznawcy Chrystusa, ale ich wpływ na wyższe warstwy społeczne nie mógł być zbyt znaczący. Trudno też określić stopień rozprzestrzenienia się chrześcijaństwa w epoce zasiedlenia. Księga o zasiedleniu wspomina jednak także o protagonistach tego procesu, którzy byli chrześcijanami. W ich gronie znalazł się Örlygur Hrappsson. Przywiózł on ze sobą drewno na kościół, żelazny dzwon, książkę z tekstami biblijnymi oraz poświęcił swoją ziemię. Osiedlił się w fiordzie, który nazwał Patreksfiord na cześć patrona i apostoła Irlandii. W późniejszym czasie osiadł w Esjuberg, gdzie wybudował farmę oraz wzniósł kościół pw. św. Kolumbana. Księga o zasiedleniu mówi też o tym, że chrześcijaństwo było dość powszechne w rejonie Kjalarnes i Akranes. Drugim znanym z imienia osadnikiem-chrześcijaninem był Helgi zwany Chudym. Wychował się w Irlandii i przybył na Islandię ze swą rodziną. Zamieszkał na północy kraju, w Eyjafiordur, i nazwał swoją farmę - Kristnes. Księga o zasiedleniu wspomina jednak, że choć wierzył w Chrystusa, to przed podróżami morskimi i w innych trudnych sprawach prosił o wstawiennictwo także Odyna. Należy 
przypuszczać, że tego rodzaju synkretyzm był dość częsty wśród osadników, którzy w zależności od sytuacji wzywali Chrystusa lub bogów pogańskich (Njardvik 54-55).

Pomimo tych dowodów na obecność chrześcijan pośród wczesnego społeczeństwa islandzkiego trzeba pamiętać, że dominującą religią pozostawały wierzenia nordyckie. Chrześcijaństwo w epoce zasiedlania było religią drugiej kategorii, wyznawali je raczej ludzie zaliczający się do niższych warstw społecznych. Choć i ta teza nie ma silnego potwierdzenia. Wielu przywódców klanów i rodów będących pierwotnie chrześcijanami często wyrzekało się chrześcijaństwa, aby w nowych warunkach utrzymać swoją pozycję i władzę. Wiązało się to z silną i ważną rolą, jaką odgrywali w lokalnych społecznościach naczelnicy rodów - godi (1.mn. godar). Słowo to wywodzi się od słowa „bóg”, stąd tytuł ten i połączona z nim funkcja, oprócz władzy cywilnej, odnosiły się także do funkcji religijnej. Pewne jest, że godair byli odpowiedzialni za budowę świątyń pogańskich w obrębie swoich farm i za organizację kultu pogańskiego (Njardvik 29-30).

Mimo iż chrześcijaństwo było początkowo w mniejszości, a nawet w stanie zaniku, to jednak z czasem stało się religią przyjętą przez cały naród. Częściowo stanowiło to konsekwencję dominującego trendu w całej ówczesnej Europie, a częściowo natury religii pogańskiej. W porównaniu z chrześcijaństwem religia pogańska nie była zorganizowana, poparta zapleczem instytucjonalnym. W rzeczywistości istniało nawet kilka systemów religijnych, które nie potrafiły dostarczyć całościowego i spójnego obrazu ludzkiego życia i śmierci. Często wymienia się dwa typy wierzeń pogańskich, obecnych pośród wikingów: wiarę w bogów nordyckich (Odyna, Thora, Freję) i wiarę w siły natury. Ten drugi nurt był bardziej prymitywny i przyjmował wiarę $\mathrm{w}$ istnienie i nadprzyrodzone zdolności istot zamieszkujących wodospady, skały czy groty. Relacje z jednymi i drugimi zakładały bardziej indywidualny, a nie zorganizowany kontakt. Bogowie pogańscy byli postrzegani i traktowani raczej jako przyjaciele. Nie byli oni też wszechmogący, nie domagali się pełnego posłuszeństwa, ale byli naznaczeni, na wzór ludzi, słabościami i zmiennością. Wiara w siły natury i licznych bogów skutkowała także różnymi koncepcjami, choćby życia po śmierci, zabobonami i przesądami. Ta słabość religii pogańskich ułatwiła i przyspieszyła przyjęcie bardziej dojrzałego i zorganizowanego chrześcijaństwa (Njardvik 55-56). Bóg chrześcijan, Chrystus, miał też tę przewagę nad bogami pogańskimi, że był ponad losem czy fatum. Ta przewaga miała duże znaczenie $\mathrm{w}$ momencie przyjmowania chrześcijaństwa (Aðalsteinsson 54). 


\section{Akcja misyjna na Islandii}

Postępy w pracy misyjnej na północy Europy (m.in. w Danii) spowodowały zainteresowanie także Islandią jako terenem misyjnym. Szczególną aktywnością misjonarską zaczął wykazywać się tutaj niemiecki Kościół. To właśnie z Niemiec przybył na Islandię Fryderyk, pierwszy znany z imienia biskup-misjonarz. Jego misja, według tradycji, miała miejsce w latach 981-986. Fryderyk pojawił się na wyspie na zaproszenie Thorvaldura Kodranssona. Przybył na wyspę i ochrzcił samego Thorvaldura, który stał się też jego tłumaczem i towarzyszem pracy. Nie znamy zbyt wielu szczegółów tej wyprawy misyjnej, poza tym, że ograniczyła się ona do północy kraju, gdzie żyła rodzina Thorvaldura. Jest prawdopodobne, że Fryderyk i jego przewodnik pojawili się na obradach Althingu, podczas których usiłowali przekonać zgromadzonych do nowej wiary. Spotkali się tam jednak z dość silną opozycją, która reprezentowała wierzenia pogańskie. Obrońcy starego porządku religijnego zastosowali przeciw głoszonemu chrześcijaństwu ośmieszający je oręż satyry. Nie mogąc pogodzić się z postawą swych ziomków, Thorvaldur zareagował gwałtownie i zabił dwu ludzi. Co prawda Fryderyk potępił ten czyn jako niezgodny z duchem chrześcijaństwa i przeciwny głoszonej wierze, jednak obydwaj misjonarze zmuszeni byli opuścić kraj, nie odnotowawszy sukcesów. Nie wiemy nic o dalszych losach biskupa Fryderyka. Thorvaldur natomiast dotarł aż na Ruś i, osiągnąwszy tam wysokie stanowisko, zmarł w Połocku (Aðalsteinsson 69-70; Byock 298; Njardvik 56).

Jak podają historycy, po opuszczeniu wyspy przez Fryderyka i Thorvaldura nastąpiła dziesięcioletnia przerwa w działalności misyjnej pośród Islandczyków (Torfason 4). Kolejny etap pracy misyjnej na Islandii miał miejsce za czasów króla Olafa Tryggvasona, który w 995 r. otrzymał koronę norweską. Przez lata wiódł on życie typowe dla wikingów, dokonując rozbojów m.in. na Bałtyku. Dwukrotnie wyprawiał się na Anglię, w 991 i 994 r. W czasie drugiej wyprawy zażądał ogromnego okupu w zamian za obietnicę nieagresji. W tym samym roku biskup Winchesteru udzielił mu bierzmowania; nie jest pewne, ale prawdopodobnie Olaf ochrzczony był już wcześniej. Jako gorliwy konwertyta powrócił do Norwegii, gdzie sięgnął po koronę królewską oraz z niezwykłym zapałem i mocą rozpoczął chrystianizację tego kraju. Swoimi misyjnymi staraniami objął także zamieszkałą w dużej mierze przez swoich rodaków Islandię. Jako pierwszego wysłał na wyspę Islandczyka Stefnira Thorgilssona, który z pomocą przydzielonych mu księży miał głosić Ewangelię. Stefnir spotkał się jednak ze słabym przyjęciem i owoce jego wyprawy nie były wielkie. To niepowodzenie spowodowało, że zaczął on niszczyć pogańskie świątynie i wizerunki pogańskich bogów. Była to zresztą metoda stosowana w Norwegii przez samego Olafa. Pozycja Stefnira nie została jednak tak ugruntowana 
i uznana jak pozycja Olafa w Norwegii, dlatego i owe próby chrystianizacji zakończyły się niepowodzeniem. Według źródeł odpowiedzią na te poczynania stało się islandzkie prawo, które stwierdzało, że wszyscy bluźniący pogańskim bogom mieli podlegać sądowi. Represje w postaci napiętnowania i niełaski mogły też dotykać nawet dalszych krewnych bluźniercy. Ostatecznie Stefnir skazany został na wygnanie, wobec czego musiał opuścić Islandię (Aðalsteinsson 70-71; Byock 298-299; Njardvik 57).

Kolejnym wysłanym z Norwegii misjonarzem był Thangbrandur. Przebywał on na Islandii prawdopodobnie w latach 996-997 lub 997-999. Jego wyprawa przyniosła większe owoce. Wędrował po kraju, szczególnie na południu, i odnotował znaczące sukcesy, gdyż ochrzcił czterech wpływowych naczelników rodów. Byli to: Gizur Teitsson ze Skálholt, Thoroddur z Olfus, Hjalti Skeggjason (zięć Gizura) i Hallur Thorsteinsson. Dwaj pierwsi piastowali funkcję godar, a dwaj ostatni odegrali potem kluczową rolę w przyjęciu chrześcijaństwa przez Islandię. Przyjęcie chrześcijaństwa przez naczelników rodów pociągało za sobą pewne komplikacje. Nie mogli oni prawdopodobnie w pełni sprawować swej funkcji i byli wykluczeni z pełnego udziału w obradach Althingu, jednak nie przestali być lokalnymi przywódcami. Stwarzało to precedens, ponieważ Althing nie mógł zgromadzić wszystkich uprawnionych do udziału w obradach. Misja Thangbradura zakończyła się połowicznym sukcesem, gdyż mimo ochrzczenia dwóch godar, chrześcijaństwo nie spotkało się z szerszym zainteresowaniem. Co więcej, misjonarz zabił dwu lub trzech ludzi, którzy go ośmieszyli, a to raczej nie zjednywało mu zwolenników. Thangbardur wyjechał do Norwegii i przedstawił królowi mizerne, jeśli chodzi o liczby, wyniki swej misji (Aðalsteinsson 63-68; Njardvik 57-58).

Odpowiedzią Olafa na opór Islandczyków wobec chrześcijaństwa było zaostrzenie kursu względem ich kraju. Norwegia zamknęła swoje porty dla kupców islandzkich oraz przejęła majątek kilku z nich, którzy przebywali akurat na jej terytorium. Sankcje miały trwać tak długo, jak długo Islandczycy pozostaną oporni wobec nowej religii. Król zagroził nawet śmiercią lub okaleczeniem zatrzymanych w Norwegii synów i krewnych prominentnych mieszkańców wyspy. Agresywne i zdecydowane posunięcia Olafa wkrótce zaczęły przynosić oczekiwane efekty. Islandczykom zależało bowiem na dobrych relacjach z Norwegią, która była ich największym partnerem handlowym. Wielu Islandczyków łączyły też z Norwegią więzy rodzinne. Wydarzenia te zbiegły się $w$ czasie także $\mathrm{z}$ przebudzeniem chrześcijan na wyspie i wzrostem ich aktywności związanej z próbami nawrócenia swoich rodaków (Byock 299).

W międzyczasie, przypuszczalnie już po opuszczeniu wyspy przez Thangbrandura, Hjalti Skeggjason zaprezentował w czasie obrad Althingu satyrę o bogini Frei, za którą został skazany na trzy lata wygnania. Nieznane są okoliczności i powody powstania tego dzieła, ale świadczy to o tym, że tamtego 
lata sprawa chrześcijaństwa powróciła na forum Althingu. Po ogłoszeniu wyroku Hjalti i jego teść Gizur Teitsson przybyli do Norwegii, na dwór Olafa. Udało się im powstrzymać króla przed spełnieniem pogróżek względem przetrzymywanych Islandczyków, a nawet uzyskać ich zwolnienie w zamian za obietnicę zaprowadzenia chrześcijaństwa wśród mieszkańców wyspy. Dzisiaj wydaje się to nieprawdopodobne, ale król rzeczywiście uwolnił uwięzionych niedawno zakładników. Zatrzymał jedynie czterech na wypadek niedotrzymania obietnicy i dalszego oporu Islandczyków wobec nowej religii. Tych czterech wybrał osobiście, i to nie tyle ze względu na okup, ile z czystej kalkulacji, gdyż byli to synowie najbardziej wpływowych naczelników i jednocześnie największych przeciwników chrześcijaństwa na Islandii (Njardvik 58).

\section{Przyjęcie chrześcijaństwa}

Latem 999 lub 1000 r. Gizur i Hjalti powrócili na Islandię. Niektórzy autorzy skłaniają się ku tezie, że dyskusja nad przyjęciem chrześcijaństwa odbyła się w dniach 23-24 czerwca 1000 r. (Magnússon 18-19; Torfason 4). Według przekazów towarzyszył im kapłan nieznanego pochodzenia, któremu Islandczycy przypisali imię Thormódur. Przybyli oni wpierw na Vestmannaeyjar, u południowych wybrzeży Islandii, w dniu, kiedy miały rozpocząć się obrady Althingu. Zamierzali od razu udać się na jego obrady, ale napotkali trudności w zdobyciu niezbędnych do podróży koni. Spowodowane było to także istnieniem $\mathrm{w}$ owym rejonie silnej opozycji przeciwko wprowadzeniu chrześcijaństwa. Ostatecznie pozyskali zwierzęta i zaczęli też gromadzić tak licznych zwolenników chrześcijaństwa, jak tylko było to możliwe. Należy pamiętać, że Hjalti, ze względu na status banity, nie mógł pojawiać się na Althingu, dlatego potrzebował poparcia i obrony ze strony swych stronników. Na czele frakcji chrześcijańskiej stanął więc Gizur Teitsson, choć i on był świadomy zagrożenia ze strony zwolenników starej religii. Potajemnie więc wysłał wiadomość do zgromadzonych, z zapytaniem o możliwość spotkania z grupą, która sympatyzowała $\mathrm{z}$ chrześcijaństwem. W tym samym czasie stronnictwo to posłało także po Hjaltiego i ostatecznie uczestniczył on w spotkaniu Althingu. Wywołało to zrozumiałe niezadowolenie frakcji pogańskiej, która nie mogła pogodzić się z obecnością osoby oskarżonej o zniewagę bogów na obradach Althingu, co było powodem napięcia i niebezpiecznej sytuacji, mogącej przeobrazić się w otwarty konflikt. Do otwartego, a nawet zbrojnego konfliktu jednak nie doszło. Trudno jednoznacznie stwierdzić, co zażegnało niebezpieczeństwo zbrojnego ataku na zwolenników nowej religii. Co więcej, Gizur i Hjalti uzyskali nawet pozwolenie na przedstawienie swojego stanowiska na forum Althingu (Aðalsteinsson 85). 
Co było przyczyną takiego obrotu sprawy? Wymienia się trzy możliwe powody. Po pierwsze, być może na spotkaniu Althingu pojawiła się większa, niż pierwotnie przypuszczano, liczba chrześcijan, z których część w obawie przed represjami nie przyznawała się wcześniej otwarcie do swoich prawdziwych sympatii. Drugi powód to ten, że tak wśród zwolenników pogaństwa, jak i chrześcijaństwa przeważyli ci, którzy pragnęli uniknąć dalszego podziału, a nawet konfliktu zbrojnego, dążąc do zachowania pokoju. Ostatnim powodem, przytaczanym głównie z chrześcijańskiego już punktu widzenia, była troska i niepewność co do losów zakładników przetrzymywanych przez króla Olafa (Njardvik 58-59).

W kolejnym dniu zgromadzenia Hjalti i Gizur przemawiali na forum Althingu. Nie ma informacji na temat ewentualnej opozycji, ale najprawdopodobniej miała ona miejsce, gdyż omawiana sytuacja oznaczała w praktyce istnienie dwu przeciwstawnych sobie wspólnot, dwu społeczności, w obrębie jednego narodu. Obydwie miałyby kierować się swoimi prawami. Powodowało to realną groźbę podziału w łonie tworzącego się jeszcze ciągle narodu. Frakcja chrześcijańska wyznaczyła spośród siebie Hallura Thorsteinssona, który miał stworzyć przepisy zgodne z chrześcijaństwem i je zaprezentować. Wyznawcy starej religii wybrali na swego przedstawiciela - Thorgeira Thorlakssona, który pełnił funkcję godi na północy kraju. Obydwaj byli „głoszącymi prawo". Warto nadmienić jeszcze, co oznaczało pojęcie "głosiciel prawa” czy „głoszący prawo”. Otóż Althing rozpoczynał się tym, że przewodniczący obradom recytował z pamięci istniejące prawo, przypominając wszystkim jego zasady. Poza tym przedstawiał zebranym do akceptacji projekty nowych ustaw. Miejscem wystąpień „głoszących prawo” była „skała prawa”, zwana też „skałą mówionego prawa”, z której przemawiano.

Hallur Thorsteinsson odmówił jednak przyjęcia oferowanej mu funkcji, obawiając się odpowiedzialności za ewentualny podział w łonie społeczeństwa, grożący podziałem państwa, a nawet wojną domową. W efekcie pogański naczelnik rodu, znawca prawa, miał zażegnać narastający konflikt i podjąć decyzję dotyczącą kluczowej wówczas sprawy, czyli przyjęcia lub odrzucenia chrześcijaństwa. Zdaniem niektórych badaczy, Hallur próbował przekupić Thorgeira. Większość jednak skłania się raczej ku wersji mówiącej o tym, że obaj wybrali drogę negocjacji i kompromisu, a nie siłowej konfrontacji i prawdopodobnego podziału kraju (Njardvik 59-60).

Tradycja mówi, że Thorgeir, obarczony odpowiedzialnością za znalezienie właściwego rozwiązania, udał się do swego szałasu i okrywszy się płaszczem, spędził $\mathrm{w}$ ten sposób resztę dnia i noc, $\mathrm{z}$ nikim nie rozmawiając i rozmyślając nad znalezieniem najlepszego rozwiązania. $Z$ jednej strony był on pogańskim - przynajmniej oficjalnie - godi i zdawał sobie sprawę z nadziei pokładanych $\mathrm{w}$ nim przez tę frakcję. $\mathrm{Z}$ drugiej miał znaleźć rozwiązanie satysfakcjonują- 
ce obydwie strony. Tyleż dziwne, co intrygujące jest schronienie się Thorgeira pod płaszcz. Niektórzy twierdzą, że doszedł on najpierw do porozumienia z przedstawicielami frakcji chrześcijańskiej i w zaciszu swego szałasu przygotowywał jedynie treść swojej przemowy, promulgującej przyjęcie nowej religii. Wydaje się jednak konieczne uwzględnienie szerszego kontekstu kulturowego tego gestu. Stare źródła islandzkie mówią o przypadkach ludzi, którzy okrywali się swoim płaszczem, by móc dostrzec i odczytać rzeczy zakryte przed ogółem. Czynili tak również poeci, by szukać inspiracji i natchnienia. Okrywanie się płaszczem było także stosowane w praktykowaniu magii i mogło też oznaczać przejście duchowej metamorfozy w czasie, gdy ciało pozostawało jakby w stanie snu czy nawet śmierci. W Laponii i Norwegii przejście przez taki proces pozwalało także na pozyskanie wiedzy z odległych, tajemnych miejsc. Praktyki te znajdują potwierdzenie również w źródłach islandzkich. Pozwala to stwierdzić, że Thorgeir nie tyle pozostawał w takim stanie, by oddać się zwykłemu rozmyślaniu, ile po to, by odbyć starożytny, znany doskonale w kręgach pogańskich rytuał. Oznaczał on, po pierwsze, zmierzenie się z problemem przerastającym zwykłe, ludzkie siły, a po drugie, nadawał decyzji nadprzyrodzone pochodzenie, co było prawdopodobnie kluczowe dla pogańskich oponentów. Wydaje się to prawdą, skoro podjęta przez Thorgeira decyzja została przyjęta przez to stronnictwo (Aðalsteinsson 103-123).

Następnego dnia wygłosił on przed zgromadzonym ludem mowę, która nie miała precedensu w całej historii Islandii. Thorgeir zdawał sobie sprawę z tego, że losy całego kraju spoczywały w tym momencie w jego rękach. Rozpoczął od ostrożnego przekonania słuchaczy, że podstawową potrzebą jest zachowanie jednego państwa i wspólnego dla wszystkich prawa. Zauważył, że trwanie przy ekstremalnie sprzecznych stanowiskach nie pozwoli na znalezienie satysfakcjonującego rozwiązania. Wskazywał na potrzebę kompromisu, który byłby odpowiedzią na potrzeby obydwu frakcji. Podkreślał, że rozdzielenie prawa (różnego dla pogan i chrześcijan) byłoby równoznaczne z podziałem państwa. Był to punkt, w którym obie frakcje zgadzały się ze sobą. W Sadze o Olafie Tryggvasonie mowa jest o tym, że wyznawcy religii pogańskiej spodziewali się decyzji biorącej stronę tego ugrupowania, gdyż Thorgeir był jednym z nich. Frakcja chrześcijańska spodziewała się natomiast werdyktu zgodnego ze spodziewaną umową, zawartą z Hallurem Thorsteinssonem. Prawdopodobnie obie strony były zaskoczone werdyktem Thorgeira, a najbardziej fanatyczni członkowie obydwu obozów, którzy mogli nawet poczuć się zdradzeni. Jednak zdecydowana większość zaakceptowała zaprezentowane rozwiązanie.

Pierwszą i najważniejszą decyzją, jaką podjął i przedstawił Thorgeir Thorkelsson, była ta, że wszyscy Islandczycy powinni przyjąć chrześcijaństwo, a ci, którzy nie zostali jeszcze ochrzczeni, mieli uczynić to jak najszybciej. 
Do tej podstawowej decyzji dołączone były trzy wyjątki, stanowiące ukłon w stronę tradycji i starej religii. Thorgeir pozwolił na: (1) utrzymanie pogańskiego zwyczaju porzucania dzieci ułomnych; (2) jedzenie koniny; (3) oddawanie czci bogom pogańskim, ale potajemne (Njardvik, 60-61).

Konieczne są pewne wyjaśnienia, związane z tymi trzema wyjątkami. Porzucanie niemowląt było normalną praktyką wśród pogan. Dzieci ułomne czy niechciane mogły być pozostawiane przed nadaniem im imienia lub zabijane. $Z$ chrześcijańskiego punktu widzenia takie praktyki były równoznaczne ze skazaniem tych dzieci na potępienie. $Z$ kolei jedzenie koniny stanowiło w czasach pogańskich praktykę powszechną, szczególnie wśród uboższych warstw, aczkolwiek zakazaną przez chrześcijan. Spożywanie mięsa końskiego było bowiem prawdopodobnie powiązane z kultami pogańskimi. Zezwolenie na kult bogów pogańskich stanowiło ukłon ku starszej generacji i miało ułatwić jak najłagodniejsze odejście od dawnej religii. Saga o Olafie Trygvassonie podaje wyjaśnienie dwóch pierwszych praktyk, które miało satysfakcjonować obydwie strony. Zgoda na nie podyktowana była tym, że obrońcom starej wiary trudno było zrozumieć z jednej strony zakaz porzucania niechcianych dzieci, a z drugiej zakaz spożywania taniego i łatwo dostępnego pożywienia. Skutkowałoby to z kolei wzrostem liczby ubogich, którzy musieliby być utrzymywani przez naczelników rodów. Argumentacja ta była też zrozumiała dla wyznających chrześcijaństwo godi (Njardvik 61). Owe praktyki zostały ostatecznie zakazane w 1016 r. (Neill 106).

Największym zwycięstwem frakcji chrześcijańskiej było to, że każdy powinien zostać ochrzczony. Bez chrztu nie ma mowy o chrześcijaństwie; to on jest sakramentem koniecznym na drodze zbawienia. $Z$ samym udzielaniem chrztu wiąże się jedno ważne wydarzenie. Otóż po wprowadzeniu obowiązku chrztu uczestnicy zgromadzenia odmówili natychmiastowego przyjęcia go w wodach Jeziora Thingvallavatn czy płynącej przez Dolinę Parlamentu rzeki Oxara. Wytłumaczeniem wydaje się niska temperatura wody i możliwość dostępu do gorących źródeł w drodze powrotnej lub w rodzinnych stronach. Całkiem prawdopodobne, że wielu z pierwszego pokolenia islandzkich chrześcijan przyjęło chrzest w dostępnych im i używanych, ciepłych źródłach (Njardvik 62; Scherman 128).

Aktualne pozostaje jednak pytanie, w jaki sposób, złożony głównie z wyznawców religii pogańskiej Althing mógł zgodzić się na przyjęcie, w pewnym sensie, obcej religii, mimo że sam stanowił prawo. Jako odpowiedź wskazuje się najpierw obawę o losy kraju, możliwość wewnętrznego rozłamu, a nawet wojny domowej, oraz troskę o utrzymanie jedności i pokoju. Niektórzy podkreślają także specyficzny charakter religii pogańskiej, której obcy był duch fanatyzmu, oraz jej słabość w przestrzeni organizacji i systemu teologicznego. Być może przyjęcie chrześcijaństwa było także świadomą decyzją przy- 
wódców klanowych, którzy postrzegali je jako religię przyszłości i nie chcieli podejmować ryzyka utraty władzy w przypadku jego zwycięstwa. Wskazuje się również na oddziaływanie norweskiego sąsiada, którego władca pozostawał bezkompromisowym krzewicielem nowej religii. Norwegia była zbyt poważnym partnerem handlowym, dlatego nie chciano utracić tego rynku. Opór wobec chrześcijaństwa mógł również ułatwić interwencję potężniejszego sąsiada w wewnętrzne sprawy kraju. Przyjęcie chrztu miało więc także wymiar polityczny, a w konsekwencji dobroczynny, jeśli chodzi o kwestię budowania narodu i państwa (Byock 301; Njardvik 62-63).

Wybór chrześcijaństwa był jednak także wyborem nowego światopoglądu i nowej, przewyższającej pogańską etyki. Z przyjęciem chrześcijańskiej wiary zmieniło się mimo wszystko traktowanie dzieci, powoli zanikała praktyka porzucania ich. Odtąd prawo dzieci do życia i edukacji było uzasadnione czymś więcej niż tylko wolą i decyzją rodziców. Przyjęcie chrześcijaństwa było znaczącym faktorem, który wyznaczał nowy kierunek w mentalności, życiu moralnym i który był początkiem nowego okresu w kulturze całego narodu (Trial 14).

Nie można też sprowadzać przyjęcia chrześcijaństwa tylko do wymiaru chłodnej kalkulacji politycznej, pozbawionej jakiegokolwiek wpływu na życie i moralność Islandczyków. Mieli oni od początku świadomość wyższości i doskonałości etyki chrześcijańskiej. Dostępna jest relacja z obrad Althingu z 1004 r., która wspomina o wystąpieniu Hjaltiego i Gizura. Była to odpowiedź na plany złożenia przez pogan ofiar z ludzi w celu powstrzymania rozprzestrzeniania się chrześcijaństwa. Hjalti zadeklarował, że chrześcijanie są także gotowi na złożenie ofiar. Składają je jednak Chrystusowi. Tą ofiarą są ludzie, którzy mają żyć dla Jego chwały i zwycięstwa. Tą ofiarą jest świadoma decyzja i zobowiązanie się do życia lepszego i gorliwszego unikania grzechu niż przed przyjęciem chrześcijaństwa (Neil 107).

Wydaje się więc, że przyjęcie chrześcijaństwa było decyzją podyktowaną także religijnymi i duchowymi racjami. O trafności wyboru i jego akceptacji świadczy również późniejsza, całkiem nieodległa historia, kreowana w dużym stopniu przez przyjętą wiarę w Chrystusa.

Początki historii narodu i państwa islandzkiego śmiało należy połączyć z okresem zdominowania historii Europy przez wikingów. Przykład ewangelizacji Islandii pokazuje jednak nieco inne oblicze ludów Północy. Wskazuje wpierw na wielki hart i determinację owych średniowiecznych imigrantów. W tym kontekście także przyjęcie chrześcijaństwa i włączenie w dominujący nurt europejskiej kultury zasługuje na uwagę, podkreślenie i docenienie. Dokonało się ono w pokojowy, a przez to kontrastujący z potocznym wyobrażeniem wikingów sposób. Było decyzją podjętą przez samych mieszkańców 
wyspy, a nie przez władcę; nie było też narzuconą z zewnątrz i utrzymaną interwencją. Było potwierdzeniem aktualności i potrzeby głoszenia Ewangelii aż po krańce ziemi. A Ultima Thule okazała się, mimo wszystko, urodzajnym gruntem pod zasiew ewangelicznego ziarna.

\title{
THE BEGINNINGS OF ICELANDIC EVANGELIZATION
}

\begin{abstract}
The turning point of Icelandic history was the reception of Christianity. After the discovery of the island, and then its settlement and the organization of an independent state, this was another step in the unification of the Icelandic nation. The circumstances of Iceland's acceptance of Christianity are peculiar in comparison with other countries in Europe at that time. While the decision to accept a new religion was usually made by the ruler, in Iceland the introduction of Christianity took place by the decision of the pagan parliament. Opposition to each other, the pagan and Christian factions, through reasonable negotiations, agreed in a bloodless manner on political agreement in this matter. The national assembly - Althingi - made a resolution in the summer of 1000 establishing a Christianity valid for the whole country religion. It is worth noting that pagan priest and clan leader Thorgeir Thorlaksson, played a crucial role here. Iceland was thus a country that was an exception to the European countries, which accepted a new faith through the conscious and voluntary decision of its inhabitants.
\end{abstract}

Keywords: Ultima Thule; the discovery of island; settlement; Althing; mission in Iceland; reception of Christianity

Słowa kluczowe: Ultima Thule; odkrycie wyspy; zasiedlenie; Althing; misje w Islandii; przyjęcie chrześcijaństwa

\section{BIBLIOGRAFIA}

Aðalsteinsson, J. Hnefill. „Under the Cloak. The Acceptance of Christianity in Iceland with Particular Reference to the Religious Attitiudes Prevailing at the Time." Studia Ethnologica Upsaliensia (1978) 4: 1-151.

Byock, Jesse. Viking age Iceland. London: Pengiun Books, 2001.

Magnússon, Sigurdur. Northern Sphinks. Iceland and Icelanders from settlement to the present. London: C. Hurst and Company, 1977.

Miotk, Andrzej. „Peregrinatio pro Christi amore we wczesnym średniowieczu.” Studia Warmińskie 39 (2002): 161-168. 
Neill, Stephen. A History of Christian Missions (The Pelican History of the Church 6). Baltimore: Pelikan, 1964.

Njardvík, Njörður. Birth of a nation. The story of the Icelandic Commonwealth. Tłum. John Porter. Reykjavík: Iceland Review, 1978.

Pálsson, Einar. Celtic Christianity in pagan Iceland. Reykjavík: Mímir, 1985.

Scherman, Katharine. Iceland: daughter of fire. London: The Travel Book Club, 1977.

Torfason, Ólafur. Kapólskur annáll Íslands: ártöl sem tengjast sögu rómversk-kapólskrar kirkju á Íslandi. Reykjavík: Porlákssjóður, 1993.

Trial, Georg. History of education in Iceland, Cambridge: W. Heffer and Sons LTD, 1945.

Wittmann, Pius. "Iceland." The Catholic Encyclopedia. Vol. 7. New York: Robert Appleton Company, 1910. 615-617.

Grzegorz Adamiak, kapłan diecezji płockiej, doktorant misjologii na Wydziale Teologicznym UKSW, duszpasterz polonijny w Islandii, administrator parafii pw. św. Jana Pawła II w Ásbrú. 